\title{
Potencjał fukoidyny jako środka wspomagającego w terapii onkologicznej
}

\section{Fucoidan and its potential as a complementary agent in cancer therapy}

\author{
Wiktoria Błaszczak ${ }^{1}$, Agnieszka Sobecka ${ }^{1,2}$,Wojciech Barczak 1,2 *, \\ Wiktoria Maria Suchorska ${ }^{1,3}$
${ }^{1}$ Pracownia Radiobiologii, Zakład Fizyki Medycznej, Wielkopolskie Centrum Onkologii, ul. Garbary 15, 61-866 Poznań ${ }^{2}$ Klinika Chirurgii Gtowy, Szyi i Onkologii Laryngologicznej, Wielkopolskie Centrum Onkologii, Uniwersytet Medyczny w Poznaniu, ul. Garbary 15, 61-866 Poznań
${ }^{3}$ Katedra i Zakład Elektroradiologii, Uniwersytet Medyczny w Poznaniu, ul. Garbary 15, 61-866 Poznań

\section{Streszczenie}

Nowotwory nadal stanowią jedną z głównych przyczyn śmiertelności w populacji światowej, a długotrwałe ich leczenie jest trudne i wysoce problematyczne, pomimo znacznego pogłębienia wiedzy z zakresu ich biologii. Obecnie wykorzystywane metody terapeutyczne cechują się wysoką toksycznością, tym samym często uniemożliwiając kontynuację leczenia i pogarszając jakość życia chorych. Z tego względu wzrasta zainteresowane środkami, które mogłyby wzmocnić skuteczność konwencjonalnej terapii lub ograniczyć występowanie poważnych skutków ubocznych. Przykładem takiej substancji jest fukoidyna - sulfonowany fukan pochodzenia naturalnego, pozyskiwany z alg i brunatnic. Istnieją liczne doniesienia potwierdzające jej efekty terapeutyczne obejmujące właściwości przeciwnowotworowe, przeciwwirusowe oraz immunomodulujące. Poniższa praca zawiera opis efektów terapeutycznych wywoływanych przez fukoidynę wyekstrahowaną z różnych gatunków alg w poszczególnych modelach nowotworów. Praca uwzględnia poznane dotychczas i proponowane mechanizmy indukcji efektów przeciwnowotworowych oraz krytyczną ocenę ograniczeń fukoidyny jako potencjalnego środka wspomagającego w terapii onkologicznej.
Abstract
Adres do korespondencji
mgr Wojciech Barczak
Pracownia Radiobiologii
Wielkopolskie Centrum Onkologii, ul. Garbary 15, 61-866 Poznań, Polska
Telefon: +48618850474
e-mail: wojciech.barczak@wco.pl

Although the knowledge on tumour biology has significantly improved in recent years, it has not yielded satisfactory effect in clinic yet, as cancer still remains one of the most common cause of death worldwide. Successful therapy still poses a challenge to physicians, as conventional treatment is highly toxic and often leads to severe adverse effects that limit benefits and significantly decrease overall quality of life. Therefore, current interests focus on development of agents that could reduce serious adverse effects incidence in 
patients and further magnify the benefits of conventional therapy. One of such agents is fucoidan, a sulfated polysaccharide derived from various algae. Many reports indicate its numerous therapeutic properties including antiviral, anticancer and immunomodulating, thus suggesting its potential use in clinic. The aim of this review is to characterize effects of fucoidan of different origin on several types of cancers with the description of its mechanisms of action along with discussion its limitations.

Słowa kluczowe: fukoidyna; nowotwór; leczenie nowotworów

Keywords: fucoidan, cancer; cancer therapy

\section{Wstęp}

W 2015 r. choroby nowotworowe stanowiły drugą najczęstszą przyczynę śmierci, odpowiadając za blisko 9 mln zgonów w populacji światowej. Według danych Światowej Organizacji Zdrowia (ang. World Health Organization, WHO) obecnie co szósty zgon spowodowany jest istniejącym nowotworem [1]. Dotychczasowe metody terapeutyczne obejmują chirurgiczną resekcję guza (guzy lite), radio- i chemioterapię oraz terapię celowaną [2].W przypadku wykorzystania cytostatyków w leczeniu nowotworów główną wadę stanowi brak specyficznościwobeckomóreknowotworowych.Prowadzitodowystępowaniaciężkichdziałańniepożądanych, które uniemożliwiając kontynuowanie terapii, przyczyniają się do ograniczenia skuteczności leczenia. Z tego względu coraz częściej uwaga badaczy i klinicystów skupia się na zastosowaniu substancji czynnych, które potencjalnie mogą przyczynić się do wzrostu efektywności stosowanego leczenia oraz ograniczyć jego toksyczność, pozwalając na dłuższe, a tym samym skuteczniejsze stosowanie chemioterapeutyków [3].

Przykładem takiej substancji jest fukoidyna - należący do grupy fukanów sulfonowany polisacharyd wchodzący w skład błon komórkowych brunatnic z rodzaju morszczynów (Fucus) oraz zwierząt wodnych zaliczanych do typu szkarłupni, takich jak strzykwy (Holothuroidea) i jeżowce (Echinoidea) [4,5]. Skład i struktura fukoidyny nie jest stała i zależy od gatunku organizmu, z którego związek został wyekstrahowany [6]. Znaczne różnice w działaniu obserwuje się w zależności od stopnia sulfonowania i acetylacji, rozgałęzienia polisacharydu, typu występujących wiązań czy masy cząsteczkowej $[7,8]$. Zainteresowanie fukoidyną nasiliło się ze względu na szereg doniesień o jej właściwościach przeciwnowotworowych, immunomodulujących, bakteriobójczych i przeciwwirusowych $[6,9,10]$. Ponadto liczne badania wykazały, że stosowanie fukoidyny sprzyja indukcji apoptozy komórek nowotworowych [11-14], hamowaniu angiogenezy [12,15,16], oraz ma działanie synergistyczne z cytostatykami i inhibitorami kinaz tyrozynowych $[17,18]$. Zastosowanie fukoidyny prowadzi do spadku proliferacji komórkowej oraz przyczynia się do zatrzymania cyklu komórkowego w różnych jego fazach $[12,14,19]$. Dotychczas fukoidyna nie została zarejestrowana jako środek terapeutyczny. Mimo to jest stosowana jako składnik suplementów diety oraz stanowi istotny element żywienia osób z populacji azjatyckiej. Nieliczne przeprowadzone do tej pory badania kliniczne skupiają się na ocenie efektów stosowania fukoidyny w niealhokolowym stłuszczeniowym zapaleniu wątroby [20], zapaleniu jelita grubego [21], chorobie zwyrodnieniowej stawów [22], jako adjuwanta wzmagającego odpowiedź na szczepienie przeciw grypie [23], oraz jako dodatku do konwencjonalnej chemioterapii (w celu zmniejszenia jej toksyczności) [24]. Niniejsza praca stanowi przegląd literatury dotyczącej charakterystyki proponowanych mechanizmów działania fukoidyny wraz z oceną jej potencjalnych zastosowań w onkologii i uwzględnieniem współistniejących im ograniczeń.

\section{Apoptoza i proliferacja}

Programowana śmierć komórki, zwana inaczej apoptozą, jest jednym z głównych narzędzi pozwalających na utrzymanie homeostazy organizmu [25]. Proces ten pozwala na usunięcie komórek uszkodzonych bez wyzwalania reakcji zapalnej [26]. Ponadto na drodze apoptozy hamowany jest podział komórek, w których materiale genetycznym wystąpiły mutacje mogące prowadzić do inicjacji procesu nowotworzenia [27]. Mechanizmy indukcji apoptozy mogą jednak zostać zaburzone [28]. W takiej sytuacji nieprawidłowa komórka przechodzi podział i zdolna jest zapoczątkować rozwój choroby [27]. Działanie przeciwnowotworowe znacznej części substancji czynnych opiera się na mechanizmach prowadzących do indukcji apoptozy w komórkach 
nowotworowych [29]. W wielu przeprowadzonych dotychczas badaniach potwierdzono zdolność fukoidyny do stymulacji apoptozy, jednak mechanizm jej indukcji różni się w zależności od źródła pochodzenia fukoidyny oraz typu nowotworu.

Tabela 1. prezentuje zestawienie efektów przeciwnowotworowych obserwowanych po zastosowaniu fukoidyny wyekstrahowanej z gatunku Fucus vesiculosus. Jest to jeden z najczęściej wykorzystywanych fukanów ze względu na swoją komercyjną dostępność.

Dotychczas skuteczność fukoidyny w indukcji procesu apoptozy wykazano w badaniach przeprowadzonych w modelach raka piersi, raka okrężnicy, raka płuca, czerniaka oraz chorób rozrostowych układu krwiotwórczego, takich jak szpiczak mnogi, czy białaczka limfoblastyczna [11,14,30-34]. W badaniach in vitro prowadzonych przez Banafę i wsp. (2013) na linii komórek raka piersi MCF-7, udowodniono zdolność fukoidyny pozyskanej z F. vesiculosus do indukcji apoptozy na drodze zależnej od translokacji cytochromu c oraz syntezy reaktywnych form tlenu. Ponadto obserwowano efekt hamowania proliferacji komórkowej, który nasilał się wraz ze wzrostem stosowanego stężenia związku. Przeciwproliferacyjny wpływ fukanów na komórki badanej linii częściowo tłumaczony jest zahamowaniem cyklu komórkowego w fazie G1 [14]. Powyższe dane potwierdzają wyniki badań uzyskane przez Hana i wsp. (2016) prowadzone na linii komórek raka pęcherza - 5637, w których potwierdzono fukoidyno-zależną indukcję apoptozy na drodze stymulacji stresu oksydacyjnego i uwolnienia cytochromu c. Udowodniono również, że spadek proliferacji komórek raka pęcherza powiązany jest z obniżeniem ekspresji podjednostki telomerazy o aktywności odwrotnej transkryptazy (ang. human telomerase reverse transcriptase, hTERT,) [13]. Podobny efekt zaobserwowano w badaniach wpływu fukoidyny pochodzącej z F. vesiculosus na proliferację komórek raka okrężnicy HCT-15. Zastosowanie fukoidyny w stężeniu $100 \mu \mathrm{g} / \mathrm{ml}$ w hodowli komórkowej prowadziło do spadku liczby żywych komórek o ponad 60\% po 24-godzinnej inkubacji oraz skutkowało zatrzymaniem 56\% komórek w fazie G1 cyklu komórkowego [32]. Kim i wsp. (2010), badając odpowiedź komórek raka okrężnicy linii HT-29 i HCT116, również obserwowali spadek proliferacji i indukcję procesu apoptozy. Mimo wykorzystania wielokrotnie niższych stężeń fukoidyny z $F$. vesiculosus $(20 \mu \mathrm{g} / \mathrm{ml})$ efekty przez nią wywoływane były zachowane dzięki trzykrotnemu wydłużeniu czasu inkubacji (do 72 godzin). Hamowanie proliferacji w wyniku zastosowania fukoidyny było silniejsze w przypadku linii HT-29. Ponadto badacze udowodnili, że zastosowanie tych samych stężeń fukoidyny pozyskanej z F. vesiculosus w hodowli prawidłowych komórek nabłonka okrężnicy (linia FHC) nie wywołuje podobnych efektów i nie wpływa na ich zdolność proliferacji [30]. Analogiczne wyniki uzyskali Xue i wsp. (2012), którzy wykazali, że ekspozycja na fukoidynę pochodzącą z F. vesiculosus skutkuje hamowaniem proliferacji komórek mysiego raka piersi (linia 4T1), jednak nie prowadzi do spadku odsetka żywych komórek w przypadku prawidłowych ludzkich fibroblastów (linia L929) [31]. Należy zauważyć, że w opisanych badaniach wykorzystano fukoidynę wyekstrahowaną z tego samego gatunku - Fucus vesiculosus, co pozwala zakładać, że efekt przeciwnowotworowy zależny jest od zastosowanej substancji czynnej, i nie od typu nowotworu. Powyższe obserwacje przemawiają za potencjalnym zastosowaniem środków terapeutycznych opartych na F. vesiculosus w leczeniu nowotworów ze względu na wysoką selektywność ich działania w stosunku do komórek nieprawidłowych. Można spekulować, że leczenie oparte na fukoidynie pochodzącej z tego gatunku umożliwiłoby uniknięcie bądź zmniejszenie częstości występowania ciężkich działań niepożądanych, tym samym poprawiając jakość życia chorych przy jednoczesnym zachowaniu właściwości terapeutycznych.

Liczne przeprowadzone dotychczas badania potwierdziły zdolność fukanów z różnych gatunków do inhibicji proliferacji i indukcji apoptozy [15,31,34], jednak nie zawsze znany jest mechanizm odpowiedzialny za wywoływanie powyższych efektów. W przypadku badań na modelu szpiczaka mnogiego, czerniaka, białaczki limfoblastycznej oraz raka płuca, mimo obserwacji efektów przeciwnowotworowych nie udało się zidentyfikować dokładnego mechanizmu hamowania wzrostu i indukcji procesu apoptozy [33,35]. Wyniki uzyskane w wyżej opisanych badaniach czynią fukoidynę wyekstrahowaną z $F$. vesiculosus potencjalną substancją uzupełniającą terapię przeciwnowotworową. Konieczne jest jednakże przeprowadzenie dalszych analiz, które pozwolą dokładnie określić mechanizmy terapeutyczne oraz potwierdzić brak toksyczności wobec komórek prawidłowych. 


\section{Angiogeneza}

Angiogeneza jest procesem powstawania nowych naczyń włosowatych [28]. Fizjologicznie zachodzi podczas rozwoju embrionalnego oraz regeneracji uszkodzonych tkanek [36]. Jednakże proces ten stanowi również kluczowy element kancerogenezy, umożliwiając efektywne odżywienie wzrastającego guza i tym samym przyczyniając się do jego rozwoju i ekspansji [37,38]. Proangiogenne właściwości nowotworu wynikają z nadekspresji czynników wzrostu w jego obrębie. Głównymi czynnnikami należącymi do tej grupy są: czynnik wzrostu śródbłonka naczyniowego (ang. vascular endothelial growth factor, VEGF), czynnik wzrostu fibroblastów (ang. fibroblast growth factor, FGF), płytkopochodny czynnik wzrostu (ang. plateletderived growth factor, PDGF, czy transformujący czynnik wzrostu beta (ang. transforming growth factor $\beta$, TGF- $\beta$ ) [39]. Ponadto obserwowane w mikrośrodowisku guza warunki hipoksji wpływają na ekspresję

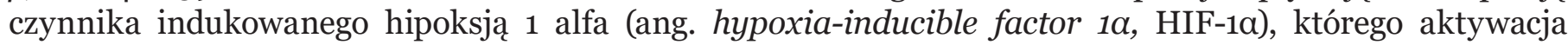
wzmaga stymulację angiogenezy [40].

Przeprowadzone dotychczas badania nad przeciwnowotworowymi właściwościami fukoidyny wykazały jej zdolność do hamowania angiogenezy w obrębie nowotworu [13,15,16,31,41]. Liu i wsp. (2016) udowodnili skuteczność fukoidyny w inhibicji waskularyzacji w przypadku modelu szpiczaka mnogiego zarówno in vitro jak i in vivo [15]. Zastosowanie fukoidyny spowodowało spadek ekspresji VEGF i HIF-1a w komórkach szpiczaka oraz osłabienie zdolności migracji i formowania kapilar przez ludzkie komórki śródbłonka żyły pępowinowej (ang. human umbilical vein endothelium cells, HUVEC). Istotne zmiany obserwowano przy zastosowaniu stężeń fukoidyny wyższych lub równych $100 \mu \mathrm{g} / \mathrm{ml}$ [12]. Wyniki te korelują z obserwacjami Xue i wsp. (2012). Przeprowadzone badania w warunkach in vitro wykazały spadek ekspresji VEGF w komórkach traktowanych fukoidyną pozyskaną z $F$. vesiculosus. Ponadto $\mathrm{w}$ badaniach in vivo także obserwowano istotnie niższą ekspresję VEGF w obrębie guzów pozyskanych od myszy (Balb/c) suplementowanych fukoidyną w porównaniu do grupy kontrolnej. Obniżony poziom VEGF miał również bezpośrednie przełożenie na liczbę naczyń w obrębie guza, która ulegała zmniejszeniu u myszy poddawanych ekspozycji na działanie fukoidyny [31]. Skuteczność fukoidyny w hamowaniu angiogenezy in vivo potwierdzona została również przez Narazaki i wsp. (2008), którzy udowodnili lepszą efektywność tego związku w wywoływaniu powyższych efektów w porównaniu do dekstranu. W badaniu wykorzystano model nowotworu in vivo. Formowanie guza indukowano u myszy poprzez podskórne podanie zawiesiny komórek linii MOPC-315, których istotną cechą jest wysoka ekspresja VEGF. Dootrzewnowe podawanie $1 \mathrm{mg}$ fukoidyny skutecznie hamowało neowaskularyzację oraz zależną od VEGF angiogenezę, jednocześnie nie wywołując objawów toksyczności [41]. Badania prowadzone nad właściwościami fukoidyny pozyskanej z alg z gatunku Sargassum hemiphyllum wykazały jej zdolność do hamowania wzrostu guza i angiogenezy in vivo poprzez obniżanie aktywacji HIF-1a stymulowanej hipoksją, ekspresji VEGF i wewnątrzkomórkowego tworzenia reaktywnych form tlenu w komórkach raka pęcherza linii T24. Ponadto nie obserwowano spadku masy ciała zwierząt traktowanych fukoidyną, co świadczy o jej dobrej tolerancji [16].

Uzyskane dotychczas wyniki opisujące zdolność fukoidyny do hamowania angiogenezy zarówno in vitro jak i in vivo przemawiają za jej potencjalnym wykorzystaniem w terapii onkologicznej. Dodatkową zaletą substancji z grupy fukanów jest ich niska toksyczność potwierdzona w badaniach na modelach zwierzęcych.

\section{Przerzutowanie}

Podczas kancerogenezy część komórek nowotworowych z puli guza pierwotnego nabiera zdolności do przerzutowania. Zdolność ta umożliwia komórkom migracjęi zasiedlanie zarówno okolicznych, jak i odległych tkanek [42]. Zjawisko przerzutowania stanowi kluczowy problem w leczeniu chorób nowotworowych, a jego wystąpienie przyczynia się do istotnego pogorszenia rokowania chorego [43]. Tworzenie przerzutów jest procesem wysoce złożonym. Jego regulacja zachodzi na drodze zależnej od wielu ścieżek sygnałowych [44]. W początkowych etapach największą rolę odgrywa poziom ekspresji enzymów proteolitycznych takich jak metaloproteinazy macierzowe czy proteazy serynowe [45]. Aktywność tych enzymów ułatwia komórkom nowotworowym opuszczenie pierwotnej niszy i migrację do światła naczyń limfatycznych bądź włosowatych poprzez degradację błony podstawnej naczyń oraz składników macierzy międzykomórkowej [45]. Do wytworzenia przerzutu w miejscu dotychczas niezasiedlonym konieczna jest neowaskularyzacja 
umożliwiająca prawidłowe odżywienie wzrastającego guza [46,47].

Badania prowadzone przez Wanga i wsp. (2014) miały na celu ocenę wpływu fukoidyny na zdolność komórek nowotworowych do inwazji i rozsiewu. Wyniki przez nich uzyskane przemawiają za skutecznością fukoidyny pochodzącej $\mathrm{z}$ gatunku Undaria pinnatifida $\mathrm{w}$ hamowaniu procesu przerzutowania mysich komórek raka wątroby (linii Hca-F) zarówno w warunkach in vitro, jak i in vivo. Badacze udowodnili, że stosowanie fukoidyny prowadzi do wzrostu ekspresji tkankowych inhibitorów metaloproteinaz: TIMP1 i TIMP-3 (ang. tissue inhibitors of metalloproteinases), oraz do spadku zdolności adhezji do płytki hodowlanej, prawdopodobnie poprzez regulację ekspresji selektyny L. Dooodatkowo autorzy zaobserwowali wpływ fukoidyny na inaktywację ścieżek sygnałowych uczestniczących $\mathrm{w}$ regulacji przerzutowania, takich jak ścieżka kinazy 3-fosfatydyloinozytolu (ang. phosphatidylinositol-4,5-bisphosphate 3-kinase, PI3K) i kinazy białkowej AKT (ang. protein kinase B, AKT) oraz ścieżki zależnej od kinaz aktywowanych mitogenami (ang. extracellular signal-regulated kinases, ERK). Ponadto masy węzłów chłonnych myszy suplementowanych fukoidyną były istotnie niższe w porównaniu do węzłów chłonnych pozyskanych od myszy niesuplementowanych [48]. Podobne wyniki uzyskali Teng i wsp. (2015) poddając ocenie skuteczność fukoidyny w hamowaniu przerzutowania indukowanego warunkami hipoksji. W badaniach autorzy wykorzystali ten sam model nowotworu (mysi rak wątroby - linia komórkowa Hca-F) oraz fukoidynę pochodzącą z gatunku Undaria pinnatifida, jako substancję czynną. Inkubacja komórek linii Hca-F z roztworem fukoidyny w warunkach niedoboru tlenu skutkowała spadkiem ekpresji HIF-1a. Zastosowanie fukoidyny pozyskanej z Undaria pinnatifida o stężeniu $400 \mu \mathrm{g} / \mathrm{ml} \mathrm{w}$ hodowli komórkowej prowadziło do spadku zdolności inwazji komórek Hca-F, zmniejszenia ekspresji metaloproteinazy 9 oraz wzrostu ekspresji TIMP-1. Ponadto wykazano również fukoidyno-zależne obniżenie poziomów komórkowych VEGF-C oraz HGF. Podobnie jak Wang i wsp. (2014) autorzy obserwowali spadek masy węzłów chłonnych myszy suplementowanych fukoidyną w porównaniu do zwierząt kontrolnych [49]. Dodatkowo Teng i wsp. (2015) wykazali związek pomiędzy ekspozycją na fukoidynę a obniżeniem zdolności komórek śródbłonka naczyń limfatycznych do tworzenia kapilar [49]. Zdolność hamowania przerzutowania przez fukoidynę pozyskaną z F. vesiculosus badana była również przez Hsu i wsp. (2012) na modelu raka piersi (linie komórek ludzkich: MCF-7, MDA-MB-231 oraz mysich: 4T1). W badaniach wykazano skuteczność fukoidyny w hamowaniu przejścia epitelialno-mezenchymalnego oraz w obniżaniu poziomu ekspresji pierwszego i drugiego receptora transformującego czynnika wzrostu beta (ang. transforming growth factor $\beta$ receptor $1 / 2$, TGF- $\beta \mathrm{R} 1 / 2$ ), co z kolei przyczynia się do ograniczenia zdolności migracji i inwazji okolicznych tkanek. Ponadto udowodniono, że spadek ekspresji TGFR wynika z jego wzmożonej ubikwityno-zależnej degradacji w proteasomie [50]. Powyższe efekty obserwowano zarówno w warunkach in vivo, jak i in vitro [50]. Kolejne badanie oceniające skuteczność fukoidyny w hamowaniu przerzutowania zostało przeprowadzone przez Huanga i wsp. (2015) z wykorzystaniem modelu raka płuca Lewisa (linia LCC). Mimo że suplementacja fukoidyną nie prowadziła do zmniejszenia masy guza in vivo, dowiedziono, że jest ona skuteczna w hamowaniu tworzenia ognisk przerzutowych indukowanych poprzez dożylne podanie zwierzętom zawiesiny komórek linii LCC. Obniżenie poziomu ekspresji metaloproteinaz, VEGF oraz jądrowego czynnika transkrypcyjnego kappa beta (ang. nuclear factor $\kappa \beta, \mathrm{NF}-\kappa \beta$ ), obserwowane wtórnie do ekspozycji na roztwory fukoidyny, pozwala zakładać, że mechanizm przeciwnowotworowy fukoidyny pochodzącej z F. vesiculosus opiera się na regulacji ekspresji powyższych czynników. Ponadto zdolność fukoidyny do hamowania rozsiewu nowotworu poprzez upośledzanie migracji i inwazji komórek została potwierdzona w teście leczenia ran (ang. wound-healing assay) oraz teście z wykorzystaniem komory Boydena (ang. chamber assay). Wyniki przeprowadzonych analiz wykazały obniżenie mobilności komórek traktowanych stężeniami fukoidyny w zakresie od o,05 do $0,4 \mathrm{mg} / \mathrm{ml} \mathrm{w}$ porównaniu do kontroli [51]. Podsumowując, wyniki opisanych badań potwierdzają przeciwnowotoworowe właściwości fukoidyny pozyskanej z gatunku $F$. vesiculosus oraz U. pinnatifida przejawiające się obniżaniem częstości przerzutowania. Zdolność do hamowania tworzenia przerzutów zależna jest zarówno od regulacji ekspresji metaloproteinaz, VEGF i HIF-1a jak i modulacji zaangażowanych w proces ścieżek sygnałowych. Udowodniono, że zastosowanie fukoidyny wyekstrahowanej z gatunku U. pinnatifida upośledza rozsiew nowotworu indukowany warunkami hipoksji, jednak efektywność fukoidyny wyekstrahowanej z F. vesiculosus w indukcji podobnych efektów nie została jeszcze zbadana. 


\section{Działanie synergistyczne z lekami}

Przez wzgląd na rosnące zainteresowanie terapeutycznymi właściwościami sulfonowanych fukanów zbadano ich potencjalną synergię $\mathrm{z}$ obecnie stosowanymi środkami terapeutycznymi. Najczęściej stosowanymi lekami w chorobach nowotworowych nadal pozostają chemioterapeutyki, takie jak pochodne platyny, taksanów czy antybiotyki peptydowe jak bleomycyna. Obecnie coraz bardziej popularne w leczeniu stają się inhibitory kinaz tyrozynowych i przeciwciała monoklonalne, których użycie umożliwia ograniczenie występowania poważnych działań niepożądanych poprzez zmniejszenie ogólnoustrojowej toksyczności terapii [52].

Thakur i wsp. (2017) oceniali efekty stosowania fukoidyny pochodzącej z U. pinnatifida wraz z inhibitorem kinaz tyrozynowych, lapanitibem, w hamowaniu proliferacji czerniaka. W powyższym badaniu wykazano, że stosowanie fukoidyny istotnie wzmacnia efekt terapeutyczny uzyskiwany poprzez podanie lapanitibu. W przypadku komórek hodowanych z kombinacją lapanitibu i fukoidyny pozyskanej z U. pinnatifida obserwowany efekt przeciwproliferacyjny był wyższy o blisko 25\% w porównaniu do wywołanego poprzez podanie wyłącznie inhibitora. Udowodniono również, że powyższy rezultat wynikał z dezaktywacji ścieżek sygnałowych zależnych od Akt i NF-kB, kluczowych dla wzrostu i proliferacji komórek czerniaka. Ponadto wykazano, że suplementacja fukoidyną myszy leczonych lapanitibem osłabia wywołany terapią spadek masy ciała i obniża częstość występowania poważnych działań niepożądanych, jednocześnie wykazując synergię z lapanitibem [18]. Skuteczność kombinacji lapanitibu i fukoidyny badana była również z wykorzystaniem innych linii komórkowych charakteryzujących się podwyższonym poziomem ekspresji receptora naskórkowego czynnika wzrostu EGFR (ang. epidermal growth factor receptor), takich jak OE19, NCI-N87, OE33, ESO26, MKN7, oraz BT474 (linie komórkowe raka przełyku, raka żołądka oraz raka piersi). W przeprowadzonych badaniach wykazano, że doustne podawanie fukoidyny nie wywołuje istotnych efektów terapeutycznych, jednakże w przypadku połączenia z lapanitibem jej działanie jest uzależnione od typu nowotworu. Działanie synergistyczne powyższych środków obserwowano jedynie w przypadku linii komórkowej raka przełyku - OE33, natomiast stosowanie obu związków w hodowli komórek linii ESO26, NCI-N87, OE19 miało efekt antagonistyczny, znosząc lecznicze działanie lapanitibu [53]. Powyższe wyniki sugerują, że efekty terapeutyczne równoczesnego stosowania fukoidyny i lapanitibu mogą być komórkowozależne i różnić się pomiędzy poszczególnymi typami nowotworów. W przypadku terapii raka piersi opartej na cytostatykach takich jak cisplatyna, tamoksifen i paklitaksel, jednoczesne podawanie fukoidyny prowadziło do wzmocnienia efektu leczniczego [54]. Zhang i wsp. (2013) badali odpowiedź komórek linii raka piersi (MDAMB-231 i MCF-7) na jednoczesne stosowanie chemioterapeutyków w połączeniu z fukoidyną wyekstrahowaną z gatunku Cladosiphon navae-caledoniae. Uzyskane przez nich wyniki świadczą o występowaniu efektu synergistycznego wybranych chemioterapeutyków i fukoidyny. Równoczesne stosowanie tych środków w hodowli komórek prowadziło do wzmożonego hamowania proliferacji, indukcji procesu apoptozy oraz zmian w przebiegu cyklu komórkowego. w porównaniu do hodowli zjedną z powyższych substancji czynnymi. Dodatkowo wykazano, że jednoczesne zastosowanie chemioterapeutyków i fukoidyny wzmaga tworzenie reaktywnych form tlenu $\mathrm{w}$ badanych komórkach [54]. Jednakże, istotnym ograniczeniem powyższego badania jest ocena odpowiedzi komórek jedynie w warunkach in vitro.

\section{Podsumowanie}

Fukoidyna jest sulfonowanym polisacharydem pochodzenia naturalnego charakteryzującym się właściwościami przeciwnowotworowymi, przeciwwirusowymi, immunomodulującymi oraz bakteriobójczymi. Ze względu na obserwowane efekty terapeutyczne wzrasta zainteresowanie wykorzystaniem fukanów w terapii onkologicznej. Udowodniono, że fukoidyna wyekstrahowana z różnych gatunków alg ma zdolność do indukcji apoptozy, hamowania proliferacji komórek nowotworowych, angiogenezy oraz przerzutowania. Może również wykazywać synergię ze środkami leczniczymi stosowanymi w konwencjonalnej terapii. Ponadto przeprowadzone dotychczas badania świadczą o niskiej toksyczności fukoidyny wobec tkanek prawidłowych i jej dobrej tolerancji. Głównymi ograniczeniami potencjalnego zastosowania fukoidyny w lecznictwie jest nadal niewystarczająca wiedza na temat mechanizmów regulacji procesu apoptozy, angiogenezy i przerzutowania oraz wpływające na skuteczność terapeutyczną istotne 
różnice w składzie i strukturze polisacharydów obserwowane w zależności od źródła pochodzenia. Z tych powodów formułowanie środka terapeutycznego na bazie fukoidyny wymaga wysokiej precyzji i musi zostać poprzedzone ścisłą oceną jej skuteczności w leczeniu danej jednostki chorobowej.

Tabela 1. Zestawienie efektów przeciwnowotworowych fukoidyny pozyskanej z gatunku Fucus vesiculosus obserwowanych w różnych modelach nowotworowych

Table 1. Anticancer effects of fucoidan derived from Fucus vesiculosus on different cancer models

\begin{tabular}{|c|c|c|c|c|}
\hline $\begin{array}{l}\text { Linia } \\
\text { komórkowa }\end{array}$ & $\begin{array}{l}\text { Model } \\
\text { nowotworu }\end{array}$ & $\begin{array}{l}\text { Hamowanie } \\
\text { proliferacji }\end{array}$ & Efekty przeciwnowotworowe & Źródło \\
\hline MOLT4 & $\begin{array}{c}\text { białaczka } \\
\text { limfoblastyczna }\end{array}$ & tak & indukcja apoptozy (mechanizm nieznany, niezależny od CD62L) & [33] \\
\hline HS-Sultan & chłoniak Burkitta & $\begin{array}{l}\text { tak, blokowanie } \\
\text { sub-G1 }\end{array}$ & indukcja apoptozy (mechanizm zależny od kaspaz) & {$[33]$} \\
\hline B16 & czerniak & tak & indukcja apoptozy (mechanizm nieznany) & {$[35]$} \\
\hline B16 & czerniak & tak & $\begin{array}{l}\text { indukcja apoptozy (mechanizm zależny od kaspaz - aktywacja } \\
\text { kaspazy 3) }\end{array}$ & {$[34]$} \\
\hline HCT116 & rak okrężnicy & tak & indukcja apoptozy (mechanizm zależny od fosforylacji p-eIF2a) & [11] \\
\hline HT29 & rak okrężnicy & & hamowanie angiogenezy (spadek ekspresji CD31, VEGF) & {$[12]$} \\
\hline HT29/ HT116 & rak okrężnicy & tak & $\begin{array}{l}\text { indukcja apoptozy (translokacja cytochromu c, wzrost } \\
\text { przepuszczalnośi błony mitochondrialnej, wzrost poziomu Bak } \\
\text { t-Bid) }\end{array}$ & [30] \\
\hline HCT15 & rak okrężnicy & tak & $\begin{array}{c}\text { indukcja apoptozy (mechanizm zależny od kaspaz, spadku ekspresji } \\
\text { Bcl-2, wzrostu ekspresji Bax, aktywacji ERK, inaktywacji PI3K) }\end{array}$ & {$[32]$} \\
\hline 5637 & rak pęcherza & $\begin{array}{c}\text { tak, blokowanie } \\
\text { w G1 }\end{array}$ & $\begin{array}{l}\text { indukcja apoptozy (mechanizm zależny od wzrostu poziomu ROS, } \\
\text { translokacji cytochromu c oraz spadku ekspresji hTERT) }\end{array}$ & {$[13]$} \\
\hline $\mathrm{MCF}-7$ & rak piersi & $\begin{array}{l}\text { tak, blokowanie } \\
\text { w G1 }\end{array}$ & $\begin{array}{l}\text { indukcja apoptozy (mechanizm zależny od kaspaz/wzrostu poziomu } \\
\text { ROS) }\end{array}$ & [14] \\
\hline MDA-MB 231 & rak piersi & tak & $\begin{array}{c}\text { indukcja apoptozy (mechanizm zależy od wzrostu ekspresji Bax } \\
\text { i kaspazy 12, fosforylacji CaMKII) }\end{array}$ & [11] \\
\hline $4 \mathrm{TI}$ & rak piersi & tak & $\begin{array}{l}\text { indukcja apoptozy (mechanizm zależny od spadku ekspresji Bcl-2); } \\
\text { hamowanie angiogenezy (spadek ekspresji VEGF) }\end{array}$ & {$[31]$} \\
\hline A549 & rak płuca & tak & indukcja apoptozy & [30] \\
\hline $\mathrm{LCC}$ & rak płuca & tak & indukcja apoptozy (mechanizm nieznany) & {$[35]$} \\
\hline $\begin{array}{l}\text { U266/ RPMI } \\
8226\end{array}$ & szpiczak mnogi & & hamowanie angiogenezy (spadek ekspresji VEGF, HIF-1a) & {$[15]$} \\
\hline IM9 & szpiczak mnogi & tak & indukcja apoptozy (mechanizm nieznany, niezależny od CD62L) & {$[33]$} \\
\hline
\end{tabular}




\section{Konflikt interesu / Conflict of interest}

Nie występuje / None

\section{Deklaracje}

Artykuł został sfinansowany ze środków Narodowego Centrum Nauki nr 2015/17/N/NZ5/oo686.

\section{Etyka / Ethics}

Treści przedstawione w artykule są zgodne z zasadami Deklaracji Helsińskiej, dyrektywami EU oraz ujednoliconymi wymaganiami dla czasopism biomedycznych.

\section{Piśmiennictwo / References}

[1] Cancer [Internet]. World Health Organization. World Health Organization; [cited 2017Apr25]. Available from: http://www.who.int/mediacentre/factsheets/fs297/en/

[2] Types of Cancer Treatment [Internet]. National Cancer Institute. National Institutes of Health; [cited 2017Apr25]. Available from: https://www.cancer.gov/about-cancer/treatment/types

[3] Cleeland CS, Allen JD, Roberts S a, Brell JM, Giralt S a, Khakoo AY, et al. Reducing the toxicity of cancer therapy: recognizing needs, taking action. Nat Rev Clin Oncol 2012; 9:1-8.

[4] Berteau O, Mulloy B. Sulfated fucans, fresh perspectives: Structures, functions, and biological properties of sulfated fucans and an overview of enzymes active toward this class of polysaccharide. Glycobiology 2003; $13: 29-40$.

[5] Kannan RRR, Arumugam R, Anantharaman P. Pharmaceutical potential of a fucoidan-like sulphated polysaccharide isolated from Halodule pinifolia. Int J Biol Macromol 2013; 62:30-34.

[6] Atashrazm F, Lowenthal RM, Woods GM, Holloway AF, Dickinson JL. Fucoidan and cancer: A multifunctional molecule with anti-tumor potential. Mar Drugs 2015; 13:2327-2346.

[7] Yang C, Chung D, Shin IS, Lee H, Kim J, Lee Y, et al. Effects of molecular weight and hydrolysis conditions on anticancer activity of fucoidans from sporophyll of Undaria pinnatifida. Int J Biol Macromol 2008; 43:433-437.

[8] Cho ML, Lee BY, You S. Relationship between oversulfation and conformation of low and high molecular weight fucoidans and evaluation of their in vitro anticancer activity. Molecules 2011; 16:291-297.

[9] Fitton JH, Stringer DN, Karpiniec SS. Therapies from fucoidan: An update. Mar Drugs 2015; 13:59205946.

[10] Kwak JY. Fucoidan as a marine anticancer agent in preclinical development. Mar Drugs 2014; 12:851870.

[11] Chen S, Zhao Y, Zhang Y, Zhang D. Fucoidan induces cancer cell apoptosis by modulating the endoplasmic reticulum stress cascades. PLoS One 2014; 9(9): e108157.

[12] Han Y-S, Lee JH, Lee SH. Antitumor Effects of Fucoidan on Human Colon Cancer Cells via Activation of Akt Signaling. Biomol Ther 2015; 23:225-32.

[13] Han MH, Lee DS, Jeong JW, Hong SH, Choi IW, Cha HJ et al Fucoidan Induces ROS-Dependent Apoptosis in 5637 Human Bladder Cancer Cells by Downregulating Telomerase Activity via Inactivation of the PI3K/Akt Signaling Pathway. Drug Dev Res. 2016.

[14] Banafa AM, Roshan S, Liu YY, Chen HJ, Chen MJ, Yang GX, et al. Fucoidan induces G1 phase arrest and apoptosis through caspases-dependent pathway and ROS induction in human breast cancer MCF-7 cells. J Huazhong Univ Sci Technol - Med Sci 2013; 33:717-724.

[15] Liu F, Luo G, Xiao Q, Chen L, Luo X, Lv J, et al. Fucoidan inhibits angiogenesis induced by multiple myeloma cells. Oncol Rep 2016; 36:1963-1972.

[16] Chen M-C, Hsu W-L, Hwang P-A, Chou T-C. Low Molecular Weight Fucoidan Inhibits Tumor Angiogenesis through Downregulation of HIF-1/VEGF Signaling under Hypoxia. Mar Drugs 2015; 13:4436-4451.

[17] Oh B, Kim J, Lu W, Rosenthal D. Anticancer effect of fucoidan in combination with tyrosine kinase 
inhibitor lapatinib. Evidence-based Complement Altern Med 2014; 865375.

[18] Thakur V, Lu J, Roscilli G, Aurisicchio L, Cappelletti M. The natural compound fucoidan from New Zealand Undaria pinnatifida synergizes with the ERBB inhibitor lapatinib enhancing melanoma growth inhibition Fucoidan extracted from New Zealand. Oncotarget 2017; 8(11): 17887-17896.

[19] Yan M De, Yao CJ, Chow JM, Chang CL, Hwang PA, Chuang SE, et al. Fucoidan elevates MicroRNA-29b to regulate DNMT3B-MTSS1 axis and inhibit EMT in human hepatocellular carcinoma cells. Mar Drugs 2015; 13:6099-6116.

[20] Taipei Medical University WanFang Hospital; Esther Prats, Taipei Medical University WanFang Hospital. Fucoidan Improves the Metabolic Profiles of Patients With Non-alcoholic Fatty Liver Disease (NAFLD). In: ClinicalTrials.gov [Internet]. Bethesda (MD): National Library of Medicine (US). 2000[cited 2017 Apr 25]. Available from: https://clinicaltrials.gov/ct2/show/results/NCTo2875392. NLM Identifier: NCTO2875392.

[21] Lean QY, Eri RD, Fitton JH, Patel RP, Gueven N. Fucoidan Extracts Ameliorate Acute Colitis. PLoS One 2015; 10:e0128453.

[22] Myers SP, Mulder AM, Baker DG, Robinson SR, Rolfe MI, Brooks L, et al. Effects of fucoidan from Fucus vesiculosus in reducing symptoms of osteoarthritis: A randomized placebo-controlled trial. Biol Targets Ther 2016; 10:81-88.

[23] Negishi H, Mori M, Mori H, Yamori Y. Supplementation of elderly Japanese men and women with fucoidan from seaweed increases immune responses to seasonal influenza vaccination. J Nutr 2013; 143:1794-8.

[24] Ikeguchi M, Yamamoto M, Arai Y, Maeta Y, Ashida K, Katano K, et al. Fucoidan reduces the toxicities of chemotherapy for patients with unresectable advanced or recurrent colorectal cancer. Oncol Lett 2011; 2:319-322.

[25] Burz C, Berindan-Neagoe I, Balacescu O, Irimie A. Apoptosis in cancer: key molecular signaling pathways and therapy targets. Acta Oncol 2011; 48:811-821.

[26] Steinman RM, Turley S, Mellman I, Inaba K. The Induction of Tolerance by Dendritic Cells That Have Captured Apoptotic Cells. J Exp Med 2000; 191:411-416.

[27] Brown JM, Attardi LD. The role of apoptosis in cancer development and treatment response. Nat Rev Cancer 2005; 5:231-237.

[28] Hanahan D, Weinberg RA. The hallmarks of cancer. Cell 2000; 100:57-70.

[29] Tesniere A, Panaretakis T, Kepp O, Apetoh L, Ghiringhelli F, Zitvogel L, et al. Molecular characteristics of immunogenic cancer cell death. Cell Death Differ 2008; 15:3-12.

[30] Kim EJ, Park SY, Lee J-Y, Park JHY. Fucoidan present in brown algae induces apoptosis of human colon cancer cells. BMC Gastroenterol 2010; 10:96.

[31] Xue M, Ge Y, Zhang J, Wang Q, Hou L, Liu Y, et al. Anticancer properties and mechanisms of fucoidan on mouse breast cancer in vitro and in Vivo. PLoS One 2012; 7:3-11.

[32] Hyun J-H, Kim S-C, Kang J-I, Kim MK, Boo HJ, Kwon JM et al. Apoptosis inducing activity of fucoidan in HCT-15 colon carcinoma cells. Biol Pharm Bull 2009; 32:1760-1764.

[33] Aisa Y, Miyakawa Y, Nakazato T, Shibata H, Saito K, Ikeda Y, et al. Fucoidan induces apoptosis of human HS-Sultan cells accompanied by activation of caspase-3 and down-regulation of ERK pathways. Am J Hematol 2005; 78:7-14.

[34] Ale MT, Maruyama H, Tamauchi H, Mikkelsen JD, Meyer AS. Fucose-containing sulfated polysaccharides from brown seaweeds inhibit proliferation of melanoma cells and induce apoptosis by activation of caspase-3 in vitro. Mar Drugs 2011; 9:2605-2621.

[35] Ale MT, Maruyama H, Tamauchi H, Mikkelsen JD, Meyer AS. Fucoidan from Sargassum sp. and Fucus vesiculosus reduces cell viability of lung carcinoma and melanoma cells in vitro and activates natural killer cells in mice in vivo. Int J Biol Macromol 2011; 49:331-336.

[36] Kerbel R, Folkman J. Clinical translation of angiogenesis inhibitors. Nat Rev Cancer 2002; 2:727-739.

[37] Carmeliet P, Jain RK. Angiogenesis in cancer and other diseases. Nature 2000; 407:249-257.

[38] Potente M, Gerhardt H, Carmeliet P. Basic and therapeutic aspects of angiogenesis. Cell 2011; 146:873887.

[39] Relf M, LeJeune S, Scott P, Fox S, Smith K. Expression of the Angiogenic Factors Vascular Endothelial 
Cell Growth Factor, Acidic and Basic Fibroblast Growth Factor, Tumor Growth Factor $\beta$-1, Plateletderived Endothelial Cell Growth Factor, Placenta Growth Factor, and Pleiotrophin in Human Primary B. Cancer Res 1997; 963-969.

[40] Ioachim E, Michael M, Salmas M, Michael MM, Stavropoulos NE, Malamou-Mitsi V. Hypoxia-inducible factors HIF-1?? and HIF-2?? expression in bladder cancer and their associations with other angiogenesisrelated proteins. Urol Int 2006; 77:255-263.

[41] Narazaki M, Segarra M, Tosato G. Sulfated polysaccharides identified as inducers of neuropilin-1 internalization and functional inhibition of VEGF 165 and semaphorin3A. Blood 2008; 111:4126-4136.

[42] Lunt S, Chaudary N, Hill R. The tumor microenvironment and metastatic disease. Clin Exp Metastasis 2009; 26:19-34.

[43] Stamenkovic I. Matrix metalloproteinases in tumor invasion and metastasis. Semin Cancer Biol 2000; 10:415-433.

[44] Deryugina EI, Quigley JP. Matrix metalloproteinases and tumor metastasis. Cancer Metastasis Rev 2006; 25:9-34.

[45] Hojilla CV, Mohammed FF, Khokha R. Matrix metalloproteinases and their tissue inhibitors direct cell fate during cancer development. Br J Cancer 2003; 89:1817-1821.

[46] Van Zijl F, Krupitza G, Mikulits W. Initial steps of metastasis: Cell invasion and endothelial transmigration. Mutat Res - Rev Mutat Res 2011; 728:23-34.

[47] Hanahan D, Weinberg RA. Hallmarks of cancer: The next generation. Cell 2011; 144:646-674.

[48] Wang P, Liu Z, Liu X, Teng H, Zhang C, Hou L, et al. Anti-metastasis effect of fucoidan from Undaria pinnatifida sporophylls in mouse hepatocarcinoma Hca-F cells. PLoS One 2014; 9:2-9.

[49] Teng H, Yang Y, Wei H, Liu Z, Liu Z, MaY, etal. Fucoidan Suppresses Hypoxia-Induced Lymphangiogenesis and Lymphatic Metastasis in Mouse Hepatocarcinoma. Mar Drugs 2015; 13:3514-3530.

[50] Hsu HY, Lin TY, Hwang PA, Tseng LM, Chen RH, Tsao SM, et al. Fucoidan induces changes in the epithelial to mesenchymal transition and decreases metastasis by enhancing ubiquitin-dependent tgfß receptor degradation in breast cancer. Carcinogenesis 2013; 34:874-884.

[51] Huang TH, Chiu YH, Chan YL, Chiu YH, Wang H, Huang KC, et al. Prophylactic administration of fucoidan represses cancer metastasis by inhibiting vascular endothelial growth factor (VEGF) and matrix metalloproteinases (MMPs) in Lewis tumor-bearing mice. Mar Drugs 2015; 13:1882-1900.

[52] Blaszczak W, Barczak W, Wegner A, Golusinski W, Suchorska WM. Clinical value of monoclonal antibodies and tyrosine kinase inhibitors in the treatment of head and neck squamous cell carcinoma. Med Oncol 2017; 34:60.

[53] Oh B, Kim J, Lu W, Rosenthal D. Anticancer effect of fucoidan in combination with tyrosine kinase inhibitor lapatinib. Evid-based Complement Altern Med 2014; 865375.

[54] Zhang Z, Teruya K, Yoshida T, Eto H, Shirahata S. Fucoidan extract enhances the anti-cancer activity of chemotherapeutic agents in MDA-MB-231 and MCF-7 breast cancer cells. Mar Drugs 2013; 11:81-98. 